\title{
Influence of Selected Cluster on the Financial Performance of Member Business Entities
}

\author{
Natalie PELLONEOVÁ, Eva ŠTICHHAUEROVÁ \\ Technical University of Liberec, Liberec, Czech Republic \\ \{natalie.pelloneova, eva.stichhauerova\}@tul.cz
}

\begin{abstract}
The paper addresses the issue of cluster performance evaluation. Under the conditions existing in the Czech Republic, the phenomenon of clusters is still new, which is why this issue deserves close attention. Despite all the benefits offered by cluster groupings, this concept is still rather new under the conditions existing in the Czech Republic and the impact of the concept of clusters on member entities' performance has not been quantified fully objectively. The aim of the present paper is to present the results of a case study focusing on the application of the EVA method to evaluate the financial performance of members of a selected cluster and to verify the assumption that business entities' membership in the cluster is reflected in increasing their financial performance in a time series. The research sample included a cluster with at least a 5-year history - given the availability of financial statements, the 2009-2014 period has been selected. This case study was prepared for the cluster entitled Clutex - Cluster of Technical Textiles that meets the above condition. The results of the research show that the expected positive effect of business entities' membership in the Clutex cluster on their financial performance has not been confirmed. The conclusion discusses possible causes of this finding.
\end{abstract}

Keywords: Cluster, Financial Performance, Economic Value Added.

\section{Introduction}

The growing importance of globalisation in today's world gives a new perspective on the development of networks and clusters. Clusters start to be perceived in a different dimension [3]. Cluster groupings are not only spontaneous grouping of companies, but rather a solid, organised structure whose basic economic effect lies in its impact on the competitiveness of businesses, regions and states [7, 5]. In the global competitive environment, only the most competitive businesses profit in the long term. According [2], companies' competitiveness is determined by their ability to innovate their products, technologies and services. Clusters could be a powerful catalyst in the innovation process and may act as interconnected territorial centres [18]. The very existence of a cluster drives competition through increasing productivity and providing an impetus for innovation and, in turn, supports future productivity growth. The cluster concept has become widely used and recognised as 
an integral part of regional development strategy and policy making in many countries [12].

Currently, the establishment and development of cluster groupings is one of the trends in national economies that offer a wide range of benefits to all stakeholders. These mainly include improved efficiency and productivity and the development of innovation activities, which contributes to improving performance and competitiveness. Within this approach, the essential hypothesis is that sufficient resources and the ability to achieve critical mass in a geographical location will provide a sustainable competitive advantage over other locations in a given economic activity. Porter argued that clusters have the potential to distort competition by increasing the productivity of companies in a cluster thanks to the driving force underpinning innovation in this area [17].

\section{$2 \quad$ Literature Review}

Networking and clustering is basically nothing new [11]. Clusters and industrial specialisations have been the focus of scientists since as early as the 19th century. However, the use of the term "cluster" in economic literature is relatively new. The development of cluster groupings did not begin until the early 1990s, when Michael Eugen Porter's ground-breaking book entitled "The Competitive Advantage of Nations" was published. In recent decades we have witnessed the use of clusters as a tool to improve competitiveness at regional and national level [6]. Clusters are perceived as an 'accelerator' of progress and competitiveness. In EU countries, stimulating cluster development has become an important element of policy. However, the choice of appropriate tools that support cluster development is a serious problem [11]. Other key questions are: what are the positive effects of cluster policy, what are the implications of clusters for economic policy makers and, last but not least, for entrepreneurs [6].

Röttmer [15] defines clusters as a regional agglomeration of companies focusing on the same technology areas that are supported by a dedicated infrastructure. The protagonists are interconnected by vertical, horizontal and lateral ties. Rugman and Verbeke [16] define a cluster as a set of interconnected organisations that are characterised by co-evolution and the associated impacts of spill-over effects. According to [18], clusters represent a higher form of cooperation between companies and other actors that can contribute to increasing the performance of a particular sector, region and state.

At present, every business is trying to achieve the highest performance possible [10]. It is generally recognised that the geographical co-location of companies has a positive effect on the economic performance of companies in a cluster. However, performance as such is not dependent on geographical proximity. Frequent exchange of knowledge and findings between businesses within a single cluster is also very important. Even though businesses within the same cluster have better opportunities to carry out this exchange than enterprises outside the cluster, these opportunities cannot be exploited without mutual trust between the various businesses [13]. 
These reasons raise the question of whether businesses in a cluster have better economic performance than businesses outside the cluster. In order to answer this question, it is necessary to examine the relationship between the performance of a cluster and the specific framework conditions. This will allow for a better understanding of the key factors of the best performing clusters [1].

Most studies in the field of economics and management assume that businesses within the same cluster are homogeneous and achieve a similar level of performance. However, in reality, businesses within a cluster show varying degrees of success. This raises an interesting question namely which factors underlie the different degree of success of companies within one cluster [13].

It is necessary to create a mechanism that will make it possible to comprehensively evaluate the performance of a business in all key areas of its activities. Cluster performance can be managed and measured in various ways and professional literature suggests a relatively large number of methods. However, to date, none of them has been identified as the most suitable. Different models are emerging within clusters and national policies. Experts' opinions on the use of performance management and measurement concepts also vary [9].

One of the concepts of performance measurement and management, namely the EVA concept, can also be used to identify the links between the benefits and performance of a business. The EVA concept can be considered as a significant criterion in business performance assessment [14]. If the EVA value is positive, the business can be considered successful because its operational activities lead to real appreciation of capital. By contrast, if the resulting value of the EVA indicator is negative, it means that the value is being destroyed by the business, as the capital invested does not cover the respective cost of that capital [8].

\section{Methods of Research}

As at 1 August 2017, there were 92 clusters and cluster organisations in the Czech Republic, of which 15 are inactive (i.e. passively awaiting their opportunity) and 5 are in liquidation (the phrase "in liquidation" is indicated after the name of the cluster).

The following section is dedicated to the case study of the cluster entitled Clutex Cluster of Technical Textiles (hereinafter Clutex). The Clutex cluster was selected because of the TUL's membership in this cluster.

\subsection{Analysis of the Clutex cluster and creation of a list of evaluated companies}

The Clutex cluster is located in the Liberec Region, the Czech Republic, and the cluster has its registered offices in the city of Liberec. Clutex was formed as an association in March 2006. In the same year, it received the "Cluster of the Year" award and it was recognised as a successful project within the Clusters programme under OPIE [4]. 
The mission of the Clutex cluster is to ensure coordination of and cooperation on activities of textile and apparel companies, research and development organisations, universities and other entities in order to create optimal conditions for technology transfer, innovation and business development in the research, development and production of technical textiles, including materials and semi-finished products used in their production [4].

In the first step of the analysis, all information available on the cluster's website was investigated. Clutex currently has 29 members (see Tab. 1). Cluster members are legal entities, namely 23 businesses, 4 research organisations, 1 university, and 1 trade union and employers' organisation. Clutex brings together legal entities operating in the textile industry and other related services, universities and secondary schools and research organisations specialising in textile technologies. The aim of this association is mainly research, development and innovation as well as cooperation with universities, secondary schools and research institutions. The Clutex cluster's main activity is to provide services for its members and develop business opportunities.

The entities participating in the cluster are based in the Pardubice, Liberec and Hradec Králové Regions. These three self-governing regions make up the Northeast NUTS 2 Cohesion Region.

Table 1 lists cluster members, including selected basic characteristics (type of organisation, legal form and average number of employees). The information below was obtained from the statutes of each cluster and on the website of the Commercial Register of the Ministry of Justice of the Czech Republic, other sources of information included and the Register of Economic Entities maintained by the Czech Statistical Office, the Access to Registers of Economic Subjects / Entities maintained by the Ministry of Finance of the Czech Republic, and the website of CzechInvest Investment and Business Development Agency.

The following table 1 lists all members of the Clutex cluster according to the statistical legal form. There are limited liability companies (112), share companies (121), university (601), state enterprise (301), and labor union and employers' organization (703).

Table 1. Members of the Clutex cluster.

\begin{tabular}{llll}
\hline Members & Type & $\begin{array}{l}\text { Statistical } \\
\text { legal form }\end{array}$ & $\begin{array}{l}\text { Average } \\
\text { number of } \\
\text { employees }\end{array}$ \\
\hline Argun s.r.o. & Business entity & 112 & 17 \\
Atok & Association & 703 & 8 \\
Elas s.r.o. & Business entity & 112 & 84 \\
GF Machinery s.r.o. & Research organizations & 112 & 7 \\
Hedva, a.s. & Business entity & 121 & 140 \\
Inotex spol. s.r.o. & Business entity & 112 & 48 \\
Intercolor, a.s. & Business entity & 121 & 119 \\
\hline
\end{tabular}




\begin{tabular}{llll}
\hline Koh-i-noor a.s. & Business entity & 121 & 148 \\
Koutný spol. s.r.o. & Business entity & 112 & 82 \\
Martilla s.r.o. & Business entity & 112 & 6 \\
Nová Mosilana, a.s. & Business entity & 121 & 886 \\
Nyklíček a spol. s.r.o. & Business entity & 112 & 96 \\
Odetka a.s. & Business entity & 121 & 41 \\
Papillons a.s. & Business entity & 121 & 46 \\
Retex a.s. & Business entity & 121 & 195 \\
S.P.M. Liberec s.r.o. & Business entity & 112 & 68 \\
Silk \& Progress, spol. s.r.o. & Business entity & 112 & 67 \\
Sintex, a.s. & Business entity & 121 & 118 \\
Stap a.s. & Business entity & 121 & 251 \\
Svitap J. H. J. spol. s r. o. & Business entity & 112 & 535 \\
Technical University of Liberec & Universities and high schools & 601 & 1034 \\
Textile Testing Institute, s. p. & Research organizations & 301 & 24 \\
Texsr, s.r.o. & Business entity & 112 & 16 \\
Vakuform s.r.o. & Business entity & 112 & 7 \\
Veba, textile plants a.s. & Business entity & 121 & 1166 \\
VÚB a.s. & Research organizations & 121 & 70 \\
VútS, a.s. & Research organizations & 121 & 176 \\
Wico B.G.M., a.s. & Business entity & 121 & 92 \\
Zitex s.r.o. & Business entity & 112 & 11 \\
\hline
\end{tabular}

The following companies belong to the category of business entities: Sintex, Nyklíček, Retex, Elas, Inotex, Argun, Intercolor, S.P.M. Liberec, Hedva, Silk \& Progress, Zitex, Stap, Veba, Koutný, Svitap J. H. J., Odetka, Nová Mosilana, Papillons, Texsr, Vakuform, Wico B.G.M., Koh-i-noor and Martilla.

Other entities of the Clutex cluster are entities that don't belong to the business entities: VÚB, VÚTS, Textile Testing Institute, Technical University of Liberec (Faculty of Textile Engineering), GF Machinery and Atok.

\subsection{Data collection from financial statements}

Since the research focused on evaluating the financial performance of cluster members, the trends in the selected EVA financial indicator were only examined for business entities within the cluster. The research does not include the performance of universities, research institutes or other "non-profit" organisations, even though they are members of this cluster. It can be concluded that business entities have a general understanding of the trends in basic financial indicators (profit, sales) and, in order to obtain accurate data, it was necessary to analyse the financial statements of these selected companies. One problem was the differences in reporting between the 
different legal forms of businesses. Individual members joined the cluster gradually over time, which is why only 'stable' members of the cluster were included in the study sample, i.e. business entities that had been cluster members for at least 5 years (see Table 2). Due to relatively poor availability of financial statements, financial statements for 2009-2014 were selected. In total, financial statements were successfully obtained for 20 companies.

\subsection{Evaluation of the performance of the Clutex cluster using the EVA method}

The Economic Value Added (EVA) indicator was used to evaluate economic performance, according to the methodology of the Ministry of Industry and Trade (hereinafter MIT). The MIT calculates the EVA indicator using an equity-based approach (1) where EVA is defined as the product of equity and 'spread' (return on equity minus alternative cost of equity):

$$
E V A=\operatorname{spread} \cdot E=\left(R O E-r_{e}\right) \cdot E
$$

$R O E$ is return on equity, $E$ is the carrying amount of equity, $r_{e}$ is an alternative cost of equity.

The indicator can only be calculated for companies with a positive equity value. Therefore, companies with zero or negative equity had to be excluded from the sample. Given the above, one business was excluded from the research.

\section{Results of the Research}

The resulting value of the EVA indicator for each business calculated for the 20092014 period (see Table 2).

Table 2. EVA in 2009-2014.

\begin{tabular}{lrrrrrr}
\hline Company & EVA09 & EVA10 & EVA11 & EVA12 & EVA13 & EVA14 \\
\hline Sintex & $-29,481.67$ & $-8,892.29$ & $-22,362.46$ & $-8,140.79$ & $-10,922.09$ & $-9,028.63$ \\
Nykliček & $-6,696.11$ & $-3,710.32$ & $-3,847.05$ & $-4,579.67$ & $-7,552.01$ & $-9,569.46$ \\
Retex & $-20,953.53$ & $-26,725.60$ & $-40,599.77$ & $-29,468.79$ & $-57,849.59$ & $-37,760.90$ \\
Elas & $-12,897.85$ & $-5,200.02$ & $-5,807.02$ & $-11,343.64$ & $-5,220.72$ & $-5,919.43$ \\
Inotex & $-11,185.98$ & $-11,847.52$ & $-4,201.44$ & $-3,546.24$ & $-1,499.85$ & $-3,294.78$ \\
Argun & -65.53 & -23.52 & -740.58 & -85.37 & $-72,828.48$ & $61,874.99$ \\
Intercolor & $-38,605.37$ & $-34,596.44$ & $-31,081.42$ & $-32,750.59$ & $-23,979.00$ & $-7,401.53$ \\
S.P.M. Liberec & $18,702.75$ & $-49,604.75$ & $-15,926.79$ & $-10,661.56$ & -7.97 & $-11,325.14$ \\
Hedva & no data & no data & no data & $-45,071.47$ & $-16,869.96$ & $-1,635.94$ \\
Silk \& Progress & -3.71 & $2,264.67$ & $3,900.25$ & $4,525.90$ & $2,147.46$ & 906.08 \\
Zitex & $-1,077.13$ & -702.15 & -665.30 & -492.56 & -505.16 & $1,497.29$ \\
\hline
\end{tabular}




\begin{tabular}{lrrrrrr}
\hline Stap & $-29,609.61$ & $-10,863.18$ & $-7,691.44$ & $-14,450.57$ & $-50,509.90$ & $17,597.05$ \\
Veba & $-53,541.78$ & $-26,391.95$ & $40,209.87$ & $158,694.31$ & $136,817.62$ & $5,608.17$ \\
Koutný & $-4,297.27$ & 724.07 & $2,076.42$ & $-4,949.16$ & $2,517.03$ & $-3,021.05$ \\
Svitap J. H. J. & $-61,733.05$ & $-35,836.03$ & $-44,627.54$ & $-47,428.30$ & $-31,752.34$ & $-28,334.43$ \\
Odetka & $-6,575.77$ & $-5,350.30$ & $-5,687.47$ & $-5,362.74$ & $-4,256.31$ & $-4,785.44$ \\
Nová Mosilana & $-69,134.47$ & $30,331.54$ & $54,326.99$ & $20,160.10$ & $-11,395.89$ & $-19,087.37$ \\
Papillons & -625.21 & 815.06 & $15,545.88$ & 920.41 & $-3,422.87$ & $-2,242.54$ \\
Texsr & 556.30 & -123.76 & -220.36 & $-1,253.76$ & no data & no data \\
\hline
\end{tabular}

Figure 1 shows the level of economic value added for each limited liability company (s.r.o.) operating within the cluster.

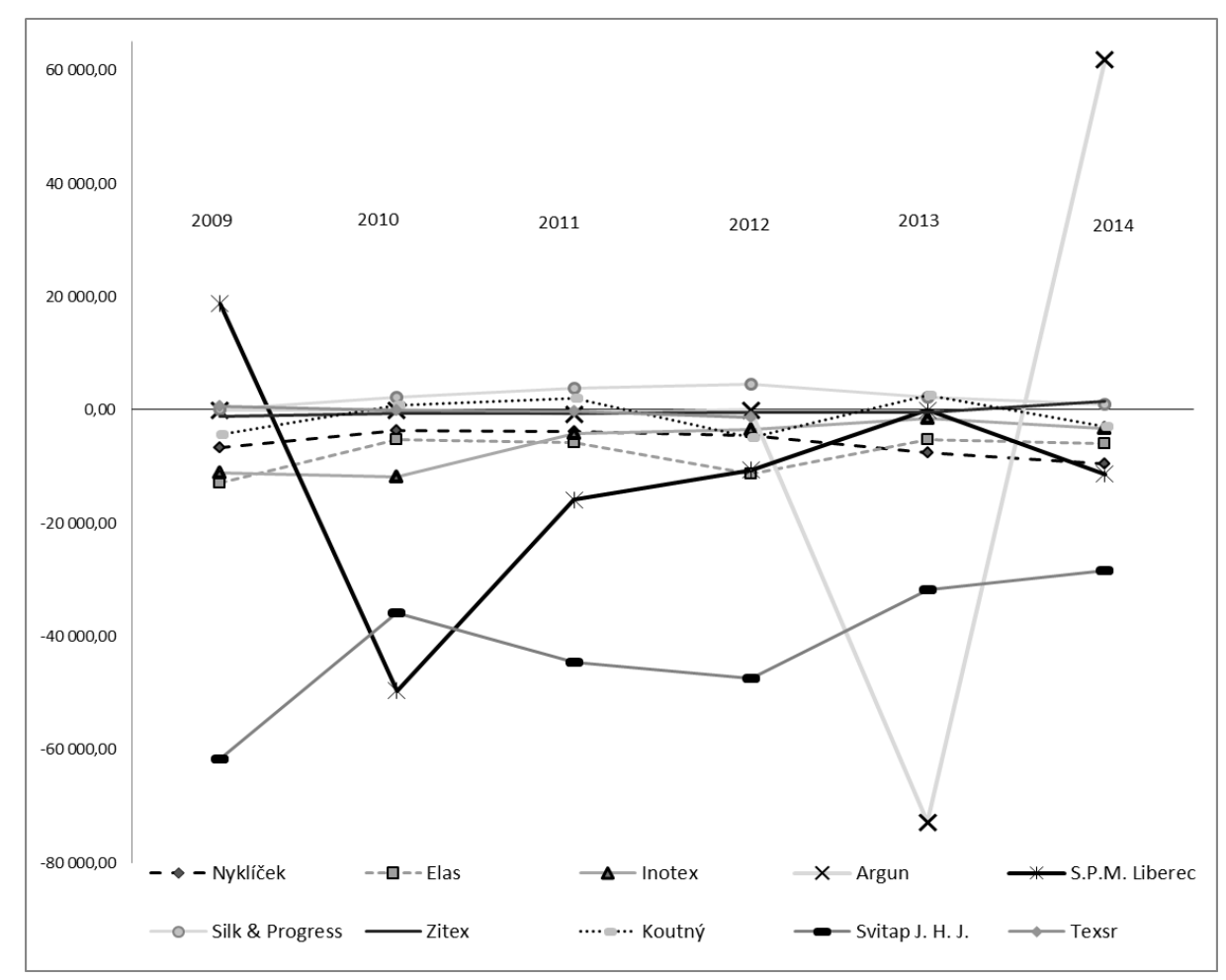

Fig. 1. EVA of limited liability companies (s.r.o.) in 2009-2014.

In the case of limited liability companies, only a few businesses generate economic value added. From 2010 to 2014, a positive value of the EVA indicator was reported by Silk \& Progress, where the value kept increasing until 2013. Since 2013, EVA has been slowly declining, but it still remains positive. Koutný achieved a positive value for the EVA indicator in 2010 and 2011. However, a year later, EVA fell to negative values. In 2013, the indicator was positive again, and a year later it dropped below a 
zero level yet again. Over the period under review, the remaining businesses consistently reported negative values, with the exception of several "shocks".

The first "shock" occurred at S.P.M Liberec in 2010, when the EVA indicator plummeted from a positive value of $18,702.75$ to a negative value of $-49,604.75$. In that year, insolvency proceedings were filed against the company. Since this major slump, the company's performance - in terms of the EVA indicator - peaked in 2013, when the company also received an award at the IDET 2013 trade fair and the owner of the company was recognised as the 2013 Manager of the Year.

The second "shock" was the massive decline in the indicator value experienced at Argun in 2013: from -85.37 to as low as $-72,828.48$. A year later, the indicator reached a positive value of $61,874.99$. It can be concluded that, over the period under review, the worst performing company - in terms of the EVA indicator - was Svitap J. H. J, whose EVA indicator value averaged $-40,000$.

Figure 2 shows the level of economic value added for each share company (a.s.) operating within the cluster.

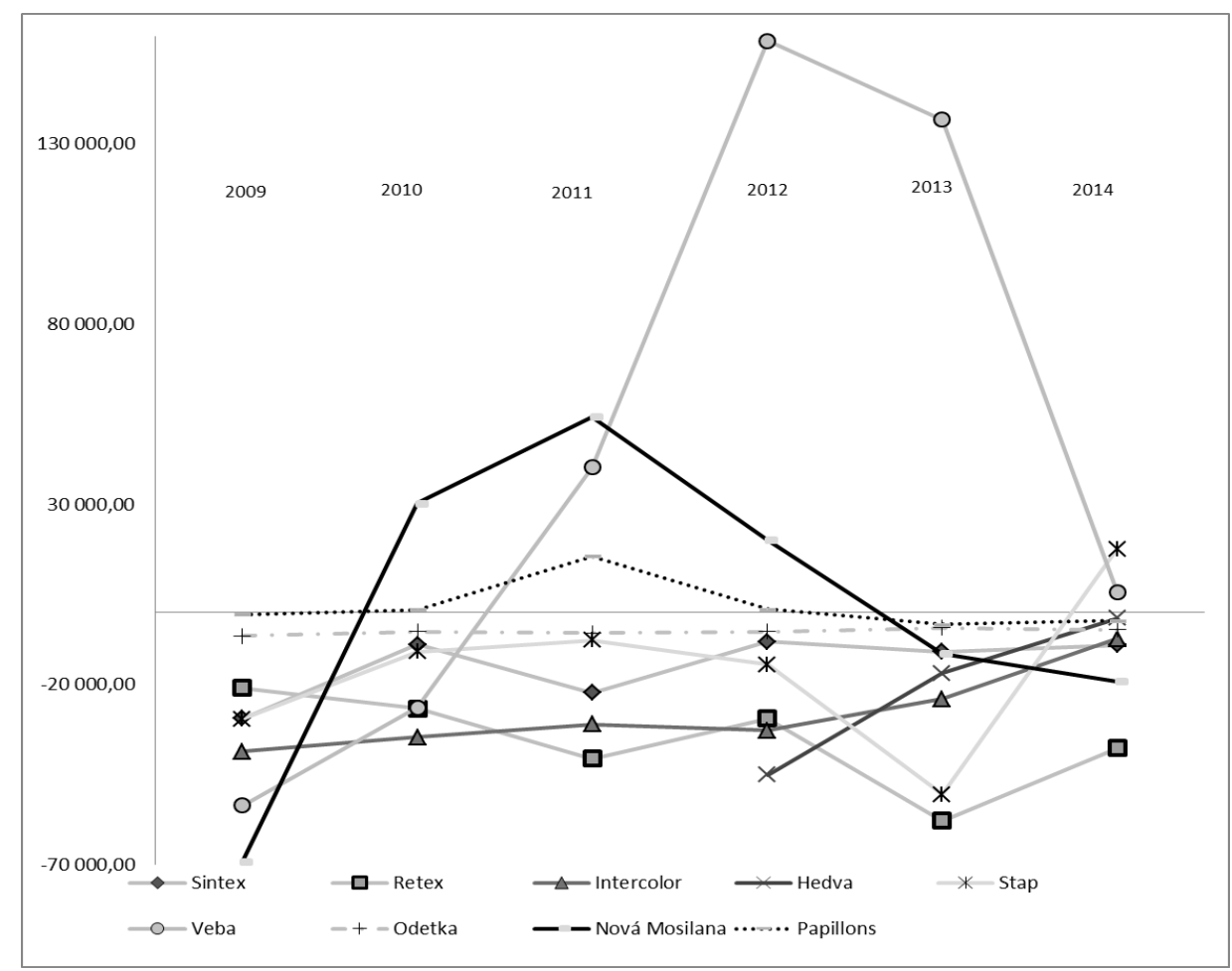

Fig. 2. EVA of share companies (a.s.) in 2009-2014.

In the case of share companies, only a few businesses generate economic value added as well. Chart 2 indicates that the values of the EVA indicator have been consistently negative for Sintex, Retex, Intercolor, Hedva and Odetka. In addition, Stap reported negative EVA indicator values until 2013. Starting in 2014, Stap's EVA reached a 
positive value for the first time. Nová Mosilana and Papillons reported positive values of the EVA indicator in 2010-2012. For both of these businesses, EVA peaked in 2012. Veba reported positive indicator values in 2011-2014, with a peak in 2012 $(158,694.31)$. Since that year, Veba's EVA has been declining. The most significant decline was recorded in 2014 when the value of the EVA indicator decreased by 131,209.45 compared to the previous year. From 2010, Veba was taking on new employees and generating hundreds of millions in profits and record sales. Its success was mainly due to flourishing exports of brocades to Africa, which accounted for $90 \%$ of the company's sales. The fall that was experienced in 2014 was caused by the on-going crisis in the African market. The company's sales fell and, at the end of 2014, the company started to downsize in order to reduce costs. While the chart does not show developments in the subsequent years, it is useful to note that, according to the company's management, the crisis factors ceased to exist and the volume of orders (especially cotton brocade for West African markets) started to increase in the second half of 2016. For 2017, the company's management is planning for an increase in sales of 40 to 50 per cent.

\section{Discussion}

Based on the analysis performed, it has not been confirmed that the businesses' participation in the Clutex cluster had a significant impact on the financial performance of each of them. Both charts above indicate that economic value added is only generated by a few businesses (and only in some years). Based on the effect of cluster participation on financial performance, the assumption was that EVA indicator values would increase in a time series due to the entity's participation in the cluster, which was not confirmed in this case. Rather, the trend in the values showed mainly sudden one-off fluctuations.

The results of this research show that the expected positive effect of business entities' membership in the Clutex cluster on their financial performance has not been confirmed. There may be several causes. It may be a specific issue of the Clutex cluster and the textile industry. It is possible that the textile sector is specific and the benefits are not proven in it. Clutex is also specific because it associates rather medium and large businesses. Other clusters have a larger share of small and medium-sized businesses.

It is interesting to see the development of EVA indicator values of all monitored businesses with respect to the global financial crisis that spread throughout the world in 2009 and caused a worldwide recession. There was no reaction showed within the development of EVA indicator values of almost all monitored business entities in the cluster. These questions can initiate further research in this area. 


\section{Conclusion}

The paper dealt with examining the impact of business entities' membership in the Clutex cluster on their financial performance. Financial performance was quantified by EVA indicator.

The Clutex cluster operates in the Northeast Cohesion Region and represents the textile and clothing manufacturers from most textile and clothing industry, representatives of suppliers and customers, and research institutions.

The research, which was conducted on the 2009-2014 data, did not confirm the assumption that its financial performance would gradually increase in a time series as a result of business entities' membership in the Clutex cluster. Possible causes of this result can be discussed. It is therefore desirable to carry out research according to the same methodology on business entities that are members of other clusters in other sectors.

Acknowledgements. Publication of this article was supported by the Czech Science Foundation (Project GACR 18-01144S: An empirical study of the existence of clusters and their effect on the performance of member enterprises).

\section{References}

1. Andersen, T., Bjerre, M., Hansson, E. W.: The cluster benchmarking project. Nordic Innovation Centre: Oslo (2006).

2. Balog, M.: Faktory rozvoja klastrových organizácií v Slovenskej republike. Ekonomický časopis 64(2), 149-168 (2016).

3. Bialic-Davendra, M.: An Investigation of a new Concept of World-Class Clusters in Europe - A Case Study of the Visegrad Group of Countries. Journal of Competitiveness 3(2), 43-57 (2011).

4. Czechinvest, http://www.czechinvest.org/clutex, last accessed 2017/08/04.

5. Dvořáček, J., Tyll, L.: Outsourcing a offshoring podnikatelských činností. 1st edn. C.H. Beck, Praha (2010).

6. Hernández-Rodríguez, C., Montalvo-Corzo, R. F.: Entrepreneurial Clusters in China and Mexico - implications for Competitiveness. Revista de Globalización, Competitividad y Gobernabilidad 6(1), 55-90 (2012). DOI: 10.3232/GCG.2012.V6.N1.04.

7. Hučka, M., Kislingerová, E., Malý, M.: Vývojové tendence velkých podniků: podniky v 21. století. 1st edn. C.H. Beck, Praha (2011).

8. Janeček, V., Hynek, J.: Motivační systém jako faktor zvyšování efektivnosti podniku. E+M Ekonomie a Management 2010(1), 76-90 (2010).

9. Jašíková, V., Marešová, P.: Aplikace metody vícerozměrného hodnocení klastrů. Acta Universitatis Bohemiae Meridionales 15(1), 77-90 (2012).

10. Jirčíková, E., Remeš, D., Pavelková, D.: Zvyšování výkonnosti podniků prostřednictvím zapojení do průmyslových klastrů. In: Medzinárodné vedecké dni 2006, pp. 164-170. Slovenská pol'nohospodárska univerzita v Nitre: Nitra (2006). 
11. Kazmierski, J.: Redefinicja roli administracji samorządowej $\mathrm{w}$ polityce wspierania rozwoju klastrów. Zarzadzanie Publiczne 2(22), 149-159 (2013), DOI: 10.4467/20843968ZP.13.013.1187.

12. Kincaid, B. L.: Competitive advantage of clusters within lesser developed countries of the South Pacific: An empirical case study extending the Porter diamond model. Capella University (2005).

13. Lei, H., Huang, CH.: Geographic clustering, network relationships and competitive advantage: Two industrial clusters in Taiwan. Management Decision 52(5), 852-871 (2014). DOI: 10.1108/MD-08-2013-0426.

14. Rajnoha, R., Dobrovič, J.: Simultánne riadenie ekonomiky a procesov znalost'ou pridanej hodnoty. E+M Ekonomie a Management 2011(1), 53-69 (2011).

15. Röttmer, N.: Innovation Performance and Clusters A Dynamic Capability Perspective on Regional Technology Clusters. 1st edn. Betriebswirtschaftlicher Verlag Gabler, Wiesbaden (2011).

16. Rugman, A. M., Verbeke, A.: Multinational Enterprises and Clusters: An Organizing Framework. Management International Review 43(3), 151-169 (2003). DOI: 10.1007/9783-322-90232-0_9.

17. Tsakalerou, M., Katsavounis, S.: Business Clusters and Knowledge Management: Information Flows and Network Concepts. In: International Conference on Intellectual Capital and Knowledge Management and Organisational Learning, pp. 632-637. Academic Conferences International Limited, Kidmore End (2013).

18. Zaušková, A.: Klastre - nástroj pre zvysovanie inovacnej výkonnosti a konkurencieschopnosti regiónov. Communication Today 7(1), 43-64 (2010). 